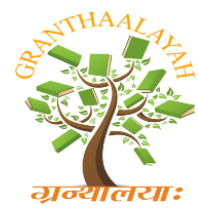

INTERNATIONAL JOURNAL OF RESEARCH GRANTHAALAYAH

A knowledge Repository

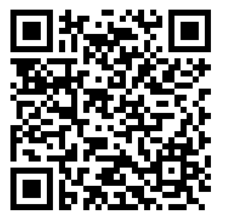

Social

\title{
TRI-GUNAS (SATTVA, RAJAS AND TAMAS) AND RISK-TAKING BEHAVIOR AMONG UNDERGRADUATE STUDENTS
}

\author{
Santosh Kumar Yadav ${ }^{* 1}$, Shiv Prakash ${ }^{2}$, Rajat Kumar Jain ${ }^{3}$ \\ *1,2 Research Scholar, Shri Shankaracharya Mahavidyalya, Junwani, Bhilai, Durg, INDIA \\ Reader in Education, Shri Shankaracharya Mahavidyalya, Junwani, Bhilai, Durg, INDIA
}

\begin{abstract}
Tri-Gunas is considered an important personality factors in the eastern philosophy. Objective of the present study is to find out co-relation between Tri-Gunas factors of personality and risk- taking behavior among undergraduate students. Sample consists of 192 under graduate students (94 male \& 98 female) selected by adopting random sampling method. The tools used for the study are Personality Assessment Profile by Dr. Upendra Dhar, Dr. Sapana Parashar and Dr. Santosh Dhar and Risk taking Questionnaire constructed by Verendra Sinha and P.N. Arora.

Statistical analysis was done by computing person's product moment co-relation. Findings of the study are -

1) Sattvic personality and risk-taking behavior are not correlated to each other significantly.

2) Rajsic personality and risk-taking behavior are not correlated to each other significantly.

3) Tamsic personality and risk-taking behavior are not correlated to each other significantly in male students but in case of female students there exists a positive and significant corelation.
\end{abstract}

Keywords:

Sattvic, Rajsic, Tamsic personality, Risk-taking behavior, Undergraduate students.

Cite This Article: Santosh Kumar Yadav, Shiv Prakash, and Rajat Kumar Jain, "TRI-GUNAS (SATTVA, RAJAS AND TAMAS) AND RISK-TAKING BEHAVIOR AMONG UNDERGRADUATE STUDENTS” International Journal of Research - Granthaalayah, Vol. 4, No. 1 (2016): 138-145.

\section{INTRODUCTION}

Personality is a very popular psychological concept of the world. Personality refers to important and relatively stable aspects of behavior. Personality deals with a wide range of human behavior. According to many theorists, personality includes virtually everything about a person mental, emotional, social, and physical. Some aspects of personality are unobservable, such as thoughts, memories, and dreams, whereas others are observable, such as overt actions. Personality also includes aspects that are concealed from yourself, or unconscious, as well as those that are 
conscious and well within your awareness. (Robert B. Ewen2003). The Indian philosophers have always acknowledged that the Supreme is the Infinite and perceived that to the soul in Nature the Infinite must always present itself in an infinite variety of aspects. We are living in a universe that is filled with great forces of life and death, creation and destruction. Divine powers can be seen everywhere lifting us into a greater sphere of peace and better understanding. But evil forces are also present around us, working to lure us down further into world of confusion and attachment. Truth and falsehood, ignorance and enlightenment and the light and dark, the illumination and shadow of the world. This concept is very indigenous to the Indian description of personality and temperament.

According to the eastern philosophy Tri-Gunas is considered an important personality concept as compared to western models of personality. Though Tri-Gunas is less popular globally, in the East, research on Tri-Guna is scarce. Interest in the area peaked in the 1970s when theoretical works led to the development of several questionnaires (Judu et.al, 2013). Triguna theory is thousand years old theory of personality which talks about not only Sattva, Rajas and Tamas Gunas but it also talks about individual and intra individual differences and it covers all major concepts, psychological processes of perception, motivation and emotion which explains clearly the differences in Sattva, Rajas, and Tamas dominant personality types.

Risk and act of risk- taking is an essential part of personality. The act of doing something that involves danger or risk in order to achieve something admirable by an individual. Matthew Tull (2014) defined that the Risk-taking refers to the tendency to engage in behaviors that have the potential to cause harm or dangers, yet at the same time provides the opportunity for some kind of outcome that can be perceived as positive. Driving fast or engaging in substance would be examples of risk-taking behavior. They may bring about positive feelings in-the-moment. However, they can also put you at risk for serious harm, such as an accident.

Risk-taking behaviors have been the subject of much speculation, from Sigmund Freud's belief that dare-devil stunts arise out of humans' innate "death drive," to some modern psychologists' view that dangerous activities can make us feel more alive. In general, we consider the behavior of risk taking as encompassing activities that only a handful of courageous, or "crazy," people would like to attempt, including skydiving, rock climbing, cliff jumping, bungee jumping or other such stunts or dramatic exploits. In reality, though, risk-taking behaviors also include more mundane acts, like having unprotected sex, gambling, robbing banks, and taking drugs. The reasons for these behaviors are complex, activities of people are important in some respect, and can mean different things to different people. In general, though, as poet Robert Browning wrote, "Our interest's on the dangerous edge of things."

One commonly accepted theory about why people do risky things has to do with evolution. This theory holds that in one of the deep, dark, old parts of our brains, where the control centers for survival and reproduction are located; there are preprogrammed impulses in some people that stimulate them to take risks. These individuals are known in psychological terms as "risk seekers," whereas their more conservative counterparts are labeled "risk avoiders." In attempting to delineate the characteristics of human risk taking, however, it is clearly being noted that one cannot make reasonable grouping of the population into risk takers and non-risk-takers. All 
people behaves differently in different situations of the world they live sometimes they are ready to take risk and sometimes avoid risk.

\section{RELATED STUDIES}

According to the Bhagavad-Gita (Vedanta philosophy) there are some descriptions can be seen about leadership and about transformational leadership. In line with the growing urge of understanding Indian philosophy and leadership. The three Gunas can also be conceptualized as a progressive development from Tamas to Rajas to Sattva and these have impact on Transformational Leadership.

Chintaharan Betal (2015) in his study which tries to investigate whether the Tri-Gunas any have role in framing of variant personality pattern. They found after analysis of the theoretical data, that a particular Guna offers specific type of behavioral pattern within the individual and thereby develops an individual's personality characteristics. Specifically that when Sattva Gunas becomes predominant, one's intellect works steadily and one becomes fearlessness, pure at heart, truthful, calm, peaceful and compassionate towards other beings. When Rajas Gunas is dominant one acts with great efforts to satisfy his desires. He becomes more passionate, more anxious, more industrious, more sensuous, more jealous and not interested in any spiritual persuasion. Tamas Gunas makes an individual's psyche; his personality displays the characteristics of ignorance, torpid and delusive. They are destructive, drowsy, aggressive, fearful and sloth by nature.

Kiran Kumar C T L and Tissy Mariam Thomas (2013) in a study based on Tri-Gunas theory of personality based on Samkhya philosophy of yoga identified four types of personalities as Sattvic, Rajasic, Sattvic-Rajasic, and Sattvic-Tamasic personalities.

Kaur and Sinha (1992) identified that Sattvic personality performance is superior than other personalities, and correspondingly the results on creativity scale show that all personality groups have a urge to be creative, but managers with Sattvic personality are able to display their creative abilities very exceptionally than other groups, thus showing their balance and harmony of mind and soul.

Khanna Pulkit et. all (2015) the Indian perspective of personality deals with the tri-dimensional classification of Gunas (Sattva, Rajas and Tamas) entailing physical, mental, and spiritual elements of personality and the relationship between Gunas and well-being indicators such as psychological capital, personality, life satisfaction, and subjective happiness. It is seen that the individuals with Sattva was found to be positively correlated with well-being. Rajas and Tamas were negatively correlated with well-being. Higher levels of Sattva and well-being were reported in the older age group. Males scored higher on Rajas while no gender differences were found in well-being.

James G. March and Zur Shapira (1987) in a study on Tri-Guna theory and risk taking found that managers take risks and exhibit risk preferences. They identified three major ways in which the conceptions of risk and risk taking held by these managers lead to orientations to risk that are different from what might be expected from a decision theory perspective: Managers are quite 
insensitive to estimates of the probabilities of possible outcomes; their decisions are particularly affected by the way their attention is focused on critical performance targets; and they make a sharp distinction between taking risks and gambling.

Nicholson et.al, (2015) found on the basis of a study on the concept of risk propensity both theoretical and empirical investigation, but with little consensus about its conceptualization and measurement of risk propensity. They found on basis of data analysis that risk propensity differs markedly in its distribution across job types and business sectors. The implications for risk research and risk management are considered.

In a study by Gabriella Anic (2007) on the association between personality and risk taking, she considered the personality factors of openness to experience, extraversion, neuroticism, agreeableness and conscientiousness. She found after stratifying by gender, only openness was still significantly associated with risk-taking. Interaction terms including gender and personality factors were added to the models to test if gender was an effect modifier. Although personality differences existed between men and women, none of the interaction terms were statistically significant.

In the present study by Judu et.al(2013) discuss the concept of Tri-Guna, characteristics of a successful personality theory and challenges in Tri-Guna research, in light of which they propose a set of eight guidelines to assist future research in the field. In addition, we discuss some of the new tools emerging from mainstream psychology, which may also be used in Tri-Gunas research.

\section{OBJECTIVE OF THE STUDIES}

To find out the relationship between Personality (Sattva, Rajas and Tamas gunas) and risk taking behavior of male and female students.

\section{HYPOTHESES -}

H1.There exists no significant co-relation between personality (Sattva Gunas) and risk taking behavior of male students.

H2.There exists no significant co-relation between personality (Sattva Gunas) and risk taking behavior of female students.

H3.There exists no significant co-relation between personality (Rajas Gunas) and risk taking behavior of male students.

H4.There exists no significant co-relation between personality (Rajas Gunas) and risk taking behavior of female students.

H5.There exists no significant co-relation between personality (Tamas Gunas) and risk taking behavior of male students.

H6.There exists no significant co-relation between personality (Tamas Gunas and risk taking behavior of female students.

\section{Sample:}

For the present study a total of 192 graduate students (94 Male and 98Female) were selected for the study by adopting random sampling method from various colleges of Durg District. 


\section{Tool:}

In the present study, Personality Assessment Profile was used to measure the personality (Sattva, Rajas and Tamas Gunas) by Dr. Upendra Dhar, Dr. Sapana Parashar and Dr. Santosh Dhar. Whereas Risk-taking behavior was measured by Risk-taking Questionnaire constructed by Verendra Sinha and P.N. Arora.

H1.There exists no significant co-relation between personality (Sattva Gunas) and risk- taking behavior of male students.

Table 4.1:

\begin{tabular}{|c|l|l|l|l|l|}
\hline $\mathbf{N}$ & \multicolumn{1}{|c|}{$\mathbf{M}$} & \multicolumn{1}{|c|}{$\boldsymbol{\Sigma} \mathbf{x}^{2}$} & $\mathbf{\Sigma y}^{\mathbf{2}}$ & $\mathbf{\Sigma} \mathbf{x y}$ & 'r' table \\
\hline & $\mathrm{M}_{1}=117.25$ & 82429.87 & 55160.81 & 540.638 & -0.008 \\
$\mathrm{~N}=94$ & $\mathrm{M}_{2}=143.276$ & & & & \\
\hline $\mathbf{d f}=\mathbf{9 3}$ & $\mathbf{P}>\mathbf{0 . 0 1}$ \\
\hline
\end{tabular}

From the table 4.1, it is evident that the co-relation for personality (Rajas Gunas) and risk- taking behavior of graduate students is -0.008 , which is not significant at 0.05 level of significance. It indicates that both variables are not significantly related to each other.

H2. There exists no significant co-relation between personality (Sattva Gunas) and risk-taking behavior of female students.

Table 4.2:

\begin{tabular}{|c|c|c|c|c|c|}
\hline $\mathbf{N}$ & $\mathbf{M}$ & $\Sigma x^{2}$ & $\Sigma \mathbf{y}^{2}$ & $\Sigma x y$ & 'r' table \\
\hline $\mathrm{N}=98$ & $\begin{array}{l}\mathrm{M}_{1}=107.11633 \\
\mathrm{M}_{2}=130.3571\end{array}$ & 96743.39 & 71010.5 & 5950.286 & 0.07 \\
\hline
\end{tabular}

We can conclude from the table 4.2, it is clear that the co-relation for personality and risk- taking behavior 0.072 which is not significant at 0.01 level of significance. It indicates that both variables are not significantly related to each other.

H3. There exists no significant co-relation between personality (Rajas Gunas) and risk- taking behavior of male students.

Table 4.3:

\begin{tabular}{|c|c|c|c|c|c|}
\hline $\mathbf{N}$ & $\mathbf{M}$ & $\Sigma x^{2}$ & $\Sigma y^{2}$ & $\Sigma x y$ & 'r' table \\
\hline $\mathrm{N}=94$ & $\begin{array}{l}M_{1}=40.74 \\
M_{2}=143.276\end{array}$ & 39977.87 & 55160.81 & 6680.81 & 0.14 \\
\hline df $=93$ & $P<0.01$ & & & & \\
\hline
\end{tabular}


It can be observed from the table 4, that the co-relation for personality (Rajas Gunas) and risk taking behavior of female graduate students is 0.14 , which is not significant at 0.01 level of significance. It indicates that both variables are not significantly related to each other.

H4. There exists no significant co-relation between personality (Rajas Gunas) and risk-taking behavior of female students.

Table 4.4:

\begin{tabular}{|c|c|c|c|c|c|}
\hline $\mathbf{N}$ & $\mathbf{M}$ & $\Sigma x^{2}$ & $\Sigma y^{2}$ & $\Sigma x y$ & 'r' table \\
\hline $\mathrm{N}=98$ & $\begin{array}{l}\mathrm{M}_{1}=43.19388 \\
\mathrm{M}_{2}=130.3571\end{array}$ & 27321.32 & 71010.50 & 9952.214 & 0.22 \\
\hline df $=97$ & $P<0.05$ & & & & \\
\hline
\end{tabular}

It can be observed from the table 4.4, that the co-relation for personality (Rajas Gunas) and risktaking behavior of female graduate students is 0.22 , which is significant at 0.05 level of significance. It indicates that both variables are significantly related to each other.

H5. There exists no significant co-relation between personality (Tamas Gunas) and risk- taking behavior of male students.

Table 4.5:

\begin{tabular}{|l|l|l|l|l|l|}
\hline $\mathbf{N}$ & $\mathbf{M}$ & $\mathbf{\Sigma} \mathbf{x}^{\mathbf{2}}$ & $\mathbf{\Sigma} \mathbf{y}^{\mathbf{2}}$ & $\mathbf{\Sigma} \mathbf{x y}$ & 'r' table \\
\hline $\mathrm{N}=94$ & $\begin{array}{l}\mathbf{M}_{1}-29.148 \\
\mathbf{M}_{2}-143.27\end{array}$ & 64943.91 & 55160.81 & 10591.73 & 0.17 \\
\hline & & $\mathbf{d f = 9 3}$ & $\mathbf{P}>\mathbf{0 . 0 1}$ & & \\
\hline
\end{tabular}

It can be observed from the table 4, that the co-relation for personality (Rajas Gunas) and risk taking behavior of female graduate students is 0.17 , which is significant at 0.01 level of significance. It indicates that both variables are not significantly related to each other.

H6. There exists no significant co-relation between personality (Tamas Gunas and risk taking behavior of female students.

Table 4.6:

\begin{tabular}{|l|l|l|l|l|l|}
\hline $\mathbf{N}$ & \multicolumn{1}{|c|}{$\mathbf{M}$} & $\mathbf{\Sigma}_{\mathbf{x}} \mathbf{2}$ & $\mathbf{\Sigma} \mathbf{y}^{\mathbf{2}}$ & $\mathbf{\Sigma} \mathbf{x y}$ & 'r' table \\
\hline $\mathrm{N}=98$ & $\mathbf{M}_{1}-31.479$ & 71870.46 & 71010.5 & 8689.214 & 0.12 \\
& $\mathbf{M}_{2}-130.35$ & & & & \\
& & & & & \\
\hline $\mathbf{d f}=\mathbf{9 7}$ & & & & \\
\hline
\end{tabular}


It can be observed from the table 4.6, that the co-relation for personality (Rajas Gunas) and risktaking behavior of female graduate students is 0.12 , which is significant at 0.01 level of significance. It indicates that both variables are not significantly related to each other.

\section{CONCLUSION}

On the basis of the study the conclusion may be drawn that we cannot generalize any confirm pattern i.e. there is certainly no fix co-relation between the two factor basic personality traits and risk-taking.

In the case of Sattvic female students are not having any clear relationship between their personality and risk -taking behavior. It is evidence on the basis of the data that they lack the property of risk taking in their behavior. In this category the Sattvic male students have no such positive co-relation with risk taking behavior.

In the case of Rajas Gunas of personality and risk-taking behavior a positive and significant corelation is found. Hence, a conclusion may be drawn that risk taking behavior is a deciding fact of rajas group. It can play a significant and vital role in their life. This kind of changes in the group of female students may be due to the changing social and political backgrounds of the girls. They are getting more opportunities in social and political fields. Constitutional provisions are also becoming the motivational factors to adopt the risk taking behavior in their life and work place as key factors. But this kind of co-relation is not seen in the Rajsic male student's personality and behavior of risk taking. Here it can be concluded that the Rajsic male students lack the behavior of risk-taking.

In the third case of Tamsik group female students no significant co-relation has been found between personality traits (Tamsik) and risk-taking factor. In the case of Tamsik male students the same kind of result has been that there exists no positive relationship between their personalities and risk taking behavior.

\section{REFRENCES}

[1] Ewen, Robert B. (2003). What is personality? Lawrence Erlbaum Associates, Publishers Mahwah, New Jersey London.

[2] lavarasu, Judu. V., Mohan, Sarasvati, \& Hankey, Alex (2013), Triguna as personality concept: Guidelines for empirical research, International Journal of Yoga Philosophy, Psychology and Parapsychology, Vol. 1, Jan-Jun-2013.

[3] Tull, Matthew (2014). http://ptsd.about.com/od/glossary/g/ risktaking.htm

[4] Freud, Sigmund. http://www.faqs.org/health/topics/15/Risk-taking-behaviors. html\#ixzz. 3te EEXIgp

[5] Dhulla, Tejal V. (2014). Transformational Leadership \&Triguna Theory: A Short Literature Review, International Journal of Advanced Research, Volume 2, Issue 5, 314-356

[6] Betal, Chintaharan (2015), Role of Trigunas In Framing Of Personality, Indian Streams Research Journal, ISSN 2230-7850, Impact Factor : 3.1560(UIF) ,Volume-5 | Issue-2 | March-2015 
[7] Kumar, Kiran C T L \& Thomas, Tissy Mariam (2013). Creativity and Triguna Personality of Managers, Volume 2 Issue 1 January 2013

[8] Khanna, Pulkit, Singh, Kamlesh, Singla, Surbhi \& Verma, Vivek (2015). September 19, IP: 103.27. 8.49

[9] March, James G. \& Shapira, Zur (1987). Managerial Perspectives on Risk and Risk Taking, Management Science, Vol. 33, No. 11, November 1987

[10] Nicholson, Nigel, Mark Fenton-O'Creevy and Emma Soane1, Paul Willman (2015).Risk Propensity and Personality

[11] Anic, Gabriella (2007). The Association between Personality and Risk Taking, Graduate Theses and Dissertations.

[12] lavarasu, Judu. V., Mohan, Sarasvati, \& Hankey, Alex (2013). Triguna as personality concept: Guidelines for empirical research, International Journal of Yoga - Philosophy, Psychology and Parapsychology, Vol. 1, Jan-Jun-2013 